\title{
Codification Theory is a Gateway for Setting Mandatory Reporting Requirements in Emerging Economies
}

\author{
Khaldoon A. Al-Htaybat ${ }^{1}$ \\ ${ }^{1}$ Accounting Department, Faculty of Economics and Administration, King Abdulaziz University, Saudi Arabia \\ Correspondence: Khaldoon A. Al-Htaybat, Accounting Department, Faculty of Economics and Administration, \\ King Abdulaziz University, P.O. Box (80201), Jeddah, 21589, Saudi Arabia. E-mail: kmahmod@kau.edu.sa
}

Received: August 6, 2014

Accepted: August 19, 2014

Online Published: October 25, 2014

doi:10.5539/ijef.v6n11p21

URL: http://dx.doi.org/10.5539/ijef.v6n11p21

\begin{abstract}
This study provides an explanation of how the process of setting new mandatory disclosure requirements in the financial reporting environment takes place by using codification theory. An empirical investigation was undertaken on the Jordanian financial reporting practices by measuring the association between the voluntary and mandatory disclosure practices of 51 manufacturing corporations before and after imposing the new Jordanian Securities Commission (JSC) mandatory requirements in 1998. The results indicate a significant, positive relationship that reflects that in 1998 the JSC took the existing Jordanian companies' voluntary financial disclosure practices and codified this practice into mandatory disclosure requirements. This paper provides evidence that will benefit future accounting standard setters as the codification of an existing optimal voluntary practice as a mandatory requirement increases the future level of compliance. This might be due to familiarity and cost effectiveness through reduced costs of compliance and analysis from a corporation's side, as well as through reduced costs associated with setting financial reporting standards, as the process can be costly for government. This paper addresses a topic that has not received appropriate attention in the extant literature, which offers a new platform for future research exploring new developments of financial reporting in relation to codification theory.
\end{abstract}

Keywords: codification theory, mandatory and voluntary disclosure, developments of financial disclosure regulation, emerging economies

\section{Introduction}

Much of the international accounting regulation and corporate annual reporting literature assumes that the form and the content of accounting and corporate reporting practices in a country is a function of its regulations' environment that exist at that time and in that place (Gray, 1988; Cooke \& Wallace, 1990; Xiao et al., 1996; Nobes, 1998; Roberts et al., 1998; Radebaugh \& Gray, 2002). These regulations are not static but change over time as they are subject to environmental factors (Von Alberti-Alhtaybat et al., 2012). However, the prior literature has not addressed any theoretical context in order to explain such developments. As an attempt to bridge this gap Von Alberti-Alhtaybat et al. (2012) raised the issue of codification theory as a theoretical foundation in the context of financial reporting requirements' developments.

Codification theory, as discussed by Von Alberti-Alhtaybat et al. (2012), argues that the development of corporate reporting regulation in the form and in the content at any time and in any place may depend upon the existing practices at that time and in that place. This theory emphasises that the already existing voluntary disclosure practices can be a major factor behind forming and developing financial disclosure standards, i.e. mandatory disclosure requirements. On the other hand, the preparers of corporate reporting and the auditors provide an optimal level of both financial and non-financial disclosure to meet users' needs, which will then be codified by regulatory bodies and regulatory setters as mandatory disclosure requirements (Von Alberti-Alhtaybat et al., 2012).

The nature of the interaction between levels of mandatory and voluntary disclosures regarding corporations' financial reporting was the concern of a few prior studies which investigated and explained how the levels of mandatory or voluntary disclosure may affect each other positively, thus resulting in increased levels of both types of disclosures (e.g. Al-Razeen \& Karbhari, 2004; Dye, 1985, 1986; Einhorn, 2005; Naser \& Nuseibeh, 2003). However, none of these studies investigated how the existing voluntary disclosure practices affect the 
increase of mandatory disclosure requirements. Furthermore, these studies do not provide a sufficient theoretical background for financial reporting research, which has resulted in a lacuna in the guidance of academic researchers.

This paper attempts to test codification theory in order to explain how the development in mandatory disclosure requirements could depend upon voluntary disclosure practices in the corporate reporting environment, to provide first time evidence based on the emerging markets' context. Jordan, like many of the emerging markets around the world, recognised a need for a change in accounting and financial reporting regulations to create a more attractive investment climate, and adopted new reform programmes aiming to create new markets and to facilitate trade with other countries (Al-Akra et al., 2009; Hutaibat et al. 2011). These reform programmes include restructuring and privatisation procedures (Al-Akra et al., 2009; Hutaibat et al. 2011). The Jordanian financial reporting environment, as one of emerging markets, is seen as a rich area to examine this theory, as in September 1997 a new Securities Law, No. 23, was issued and the Jordanian financial market was transformed into a modern capital market with a new legal framework. This included new financial disclosure requirements imposed upon companies listed on the Amman Stock Exchange (ASE) since 1998. For the first time according to the new Jordanian financial market regulations, the listed Jordanian companies were required to apply IASs in periodic financial statements. The underlying aim of the accounting regulation modifications in Jordan was to create an attractive investment climate to encourage both domestic and foreign investors. This raises the research question of whether the new implications of mandatory disclosure requirements by the JSC in 1998 were associated with voluntary financial disclosure practices prior to 1998. Therefore, an empirical investigation to examine codification theory in Jordan, as one of the emerging economies with a new reform programme, is considered useful.

The next section of this paper outlines the current research objectives, questions, hypotheses, research method, and sample. The third section illustrates the analyses, which is then followed by discussion and conclusion.

\section{Literature Review}

In the corporate reporting literature, there are hundreds of prior studies that measured the levels of both voluntary and lor mandatory printed and Internet financial disclosure. A list of prior empirical studies on financial reporting since 1961 is provided in Table 1.

Table 1. Prior empirical studies of printed financial disclosure

\begin{tabular}{|c|c|c|c|c|c|}
\hline Year & Authors & Countries & Mandatory (M) & Voluntary (V) & Both $(M+V)$ \\
\hline \multicolumn{6}{|c|}{ A: Studies of developed countries } \\
\hline 1961 & Cerf & USA & & & - \\
\hline 1971 & Singhvi and Desai & USA & & & $\bullet$ \\
\hline 1975 & Buzby & USA & & & - \\
\hline $1979 a, b$ & Firth & UK & & - & \\
\hline 1980 & Firth & UK & & • & \\
\hline 1982 & McNally et al. & New Zealand & & - & \\
\hline 1989 & Cooke & Sweden & & & - \\
\hline 1991 & Cooke & Japan & & - & \\
\hline $1992 / 3$ & Cooke & Japan & & & $\bullet$ \\
\hline 1993 & Malone et al. & USA & & & $\bullet$ \\
\hline 1994 & Wallace et al. & Spain & - & & \\
\hline 1995 & Raffournier & Switzerland & & - & \\
\hline 1995 & Meek et al. & USA, UK and Europe & & - & \\
\hline 1997 & Inchausti & Spain & & & - \\
\hline 2000 & Depoers & France & & • & \\
\hline 2001 & Watson et al. & UK & & - & \\
\hline \multicolumn{6}{|c|}{ B: Studies of developing countries } \\
\hline 1967 & Singhvi & India & & & $\bullet$ \\
\hline 1987 & Chow and Wong-Boren & Mexico & & - & \\
\hline 1988 & Wallace & Nigeria & & & $\bullet$ \\
\hline 1990 & Benjamin et al. & Hong Kong (HK) & $\bullet$ & & \\
\hline 1993 & Mutter & Jordan & $\bullet$ & & \\
\hline 1993 & Abayo et al. & Tanzania & & & - \\
\hline
\end{tabular}




\begin{tabular}{|c|c|c|c|c|c|}
\hline 1994 & Ahmed and Nicholls & Bangladesh & - & & \\
\hline 1994 & Hossain et al. & Malaysia & & - & \\
\hline 1994 & Solas & Jordan & $\bullet$ & & \\
\hline 1995 & Wallace and Naser & Hong Kong & - & & \\
\hline 1995 & Al-Modakhi & Saudi Arabia & & & $\bullet$ \\
\hline 1997 & Al-Mulhem & Saudi Arabia & & & $\bullet$ \\
\hline 1997 & Suwaidan & Jordan & & - & \\
\hline 1997 & Patton and Zelenka & Czech Republic & $\bullet$ & & \\
\hline 1998 & Naser & Jordan & & - & \\
\hline 1998 & Owusu-Ansah & Zimbabwe & $\bullet$ & & \\
\hline 1999 & Alrazeen & Saudi Arabia & & & $\bullet$ \\
\hline 1999 & Curuk & Turkey & $\bullet$ & - & $\bullet$ \\
\hline 2000 & Naser and Al-Khatib & Jordan & & $\bullet$ & \\
\hline 2001 & Al-Hussaini & Kuwait & & & $\bullet$ \\
\hline 2002 & Chau and Gray & HK and Singapore & & $\bullet$ & \\
\hline 2002 & Haniffa and Cooke & Malaysia & & - & \\
\hline 2003 & Naser and Nuseibeh & Saudi Arabia & & & $\bullet$ \\
\hline 2005 & Akhtaruddin & Bangladesh & - & & \\
\hline 2009 & Dahawy & Egypt & • & & \\
\hline 2009 & Hossain and Hammami & Qatar & & - & \\
\hline 2010 & Abdur Rouf & Bangladesh & & • & \\
\hline $2010 \mathrm{a} / \mathrm{b}$ & Al-Akra et al. & Jordan & - & - & \\
\hline 2011 & Omar and Simon & Jordan & & & $\bullet$ \\
\hline 2011 & Hutaibat et al. & Jordan & - & & \\
\hline
\end{tabular}

Reviewing the prior studies listed in Table 1 shows that prior empirical studies examined financial disclosure focusing mainly on developed countries or developing countries by using a disclosure index approach. Also the review of these studies, see Table 1, shows that there were three main research dimensions to measure the extent of financial disclosure: Firstly, researchers that sought to measure the extent of voluntary disclosure assumed either that there was full compliance with mandatory disclosure requirements or mandatory disclosure requirements were not existent in their research setting. Secondly, researchers measured the level of mandatory disclosure without looking at voluntary disclosure as well. Thirdly, researchers measured the overall level of financial disclosure, including mandatory and voluntary items.

These studies also measured the relationship between the level of financial disclosure and various company characteristics as independent variables, which range from one variable (ownership form, that is, whether or not family owners are dominant - Chau \& Gray, 2002) to fourteen variables (company size, assets in place, industry type, listing age, complexity of business, level of diversification, multiple listing status, foreign activities, gearing, top ten shareholders, foreign ownership, institutional investors, profitability, and type of auditors Haniffa \& Cooke, 2002). Ahmed and Courtis (1999) documented that company size, listing status, leverage, profitability, and size of auditor were the most frequently tested company characteristics in prior studies. Furthermore, Wallace et al. (1994), Ahmed and Courtis (1999), and Haniffa and Cooke, (2002) stated that the selection of the company characteristics as independent variables was mainly justified by using signalling theory, agency theory, cost benefit theory and capital need theory.

These theories were used to explain different sub-points of financial disclosure and provide explanations for variations in financial disclosure among companies. These include the agency problem (Jensen \& Meckling, 1976) and information asymmetry (Akerlof, 1970), the need for disclosure regulations (Posner, 1974; Cooper \& Keim, 1983), the reasons behind managers' incentives for more disclosure (Watts \& Zimmerman, 1978, 1986), and the objective to raise company capital as cheaply as possible (Choi, 1973). Also theoretical explanations are utilised to distinguish the value or quality of a company's product (Akerlof, 1970; Strong \& Walker, 1987). Prior scholars explained the variations in the financial disclosure practices among countries, based on the environmental factors underlying financial disclosure differences (Gray, 1988; Cooke \& Wallace, 1990; Nobes, 1998; Roberts et al., 1998; Radebaugh \& Gray, 2002). Recently, a technological factor, the Internet, was included as a new element influencing the form and content of financial reporting, and this particular technology has fortified the development from the printed to the Internet financial reporting format (Xiao et al., 1996; Xiao et al., 2002). 
These theories suggest that managers have their own reasons to disclose accounting information to users in order to reduce agency cost, political costs, to raise capital as cheaply as possible, or even to distinguish their companies from other companies (Von Alberti-Alhtaybat et al., 2012). Also these incentives are based on the trade-off between the costs and benefits of providing such information, due to which the managers' choices to provide more information are based on a comparison between the costs of information that will be provided and the benefits that might arise from disclosing such information (Cooke, 1992). This is referred to as "cost-benefit theory" (Haniffa \& Cooke, 2002, p. 327). Nevertheless managers' incentives are different from one company to another according to several company characteristics which create variation at the level of voluntary disclosure practices, and which are used in prior studies to explain the differences in the levels of printed and Internet financial disclosure among companies (Von Alberti-Alhtaybat et al., 2012).

During the last two decades the emergence of technology in corporate disclosure, in the form of voluntary Internet reporting, has opened up a new research arena for voluntary financial disclosure practice (Al-Htaybat, 2011). Managerial incentive theories were employed since the late 1990s to explore the practices of voluntary Internet reporting, which resulted in an extensive research in various Western, Australasian and Middle Eastern countries. These include in the US: Ashbaugh et al. (1999), and Ettredge et al. (2002). Other research studies were undertaken by Craven and Marston (1999) in the UK; Gowthorpe and Amat (1999) in Spain; Pirchegger and Wagenhofer (1999) in Austria; Bonson and Escobar (2002) in 15 European countries; Marston and Polei (2004) in Germany; Andrikopoulos (2007) in Cyprus; Bozcuk et al (2008) in Turkey and Despina and Demetrios (2009) in Greece. Also several studies have focused on Australasian countries, including studies by Oyelere et al. (2003) in New Zealand; Marston (2003) in Japan, Lai et al. (2010) in Taiwan, Verma (2010) in India, Xiao et al. (2004) and Zhang et al (2007) in China. Finally, Middle Eastern countries were subject to a number of studies for instance: Joshi and Al-Modhahki (2003) in Kuwait and Bahrain, Desoky (2009) and Aly et al. (2010) in Egypt, and Momany and Al-Shorman (2006), Al-Htaybat and Napier (2006), Al-Hayale (2010), and Al-Htaybat (2011) in Jordan.

Methodologically, prior printed and Internet financial disclosure studies have extensively employed one research method, a disclosure index approach, either weighted or un-weighted, as the main research tool to measure the quantity of financial disclosure, depending on their research objective (Hanafi et al., 2009). The un-weighted dichotomous disclosure index is used to measure the quantity of disclosed items within the annual report, as items are scored as one or zero depending on whether or not they were disclosed in the annual report (Hanafi et al., 2009). The weighted disclosure index is used to assess quality of disclosed items by weighting the index, either by researchers themselves or by others, to reflect the importance of each item disclosed in the annual report (see Hanafi et al., 2009; Marston \& Polei, 2004; Xiao et al., 2004).

The disclosure index approach was analysed by many studies in the context of printed and Internet financial reporting studies, such as Marston and Shrives (1991); Ahmed and Courtis (1999); Coy and Dixon (2004); Guthrie and Abeysekera (2006) and Hanafi et al. (2009). These authors summarised the disclosure index as a well-established research method in the area of financial reporting, which is based on the general principles of thematic analysis. Such analysis can be used to undertake a manual content analysis that is converted to measure structured and/or unstructured narrative and/or non-narrative, regulated and/or voluntary financial and/or nonfinancial disclosures by classifying a checklist of particular items and using a specific coding scheme to demonstrate the disclosed and/or not disclosed information in both the main text and/or companies' accounts in the annual reports, and calculating the ratio of items disclosed to the maximum disclosure set (see for example Beattie et al., 2004; Coy \& Dixon, 2004; Guthrie \& Abeysekera, 2006; Hanafi et al., 2009). However, these prior checklists in terms of items included have varied from one study to another based on each study's objectives, and as there is no generally agreed upon theory on constructing disclosure indices in the area of financial reporting (Wallace \& Naser, 1995).

Similarly, the method of the disclosure index was utilised to investigate mandatory and voluntary disclosure requirements. With regard to the interaction between mandatory and voluntary disclosure, Dye (1986) states that in practice mandatory disclosure requirements do not develop due to exogenous reasons, but that the existence of these disclosure requirements could originate from companies' voluntary disclosure practices. Accounting standard setters could use these voluntary practices to issue new mandatory financial disclosure requirements by codifying the existing voluntary practices. Already existing practice influences and inputs on the standard setting process because what is currently done in practice is likely to represent a great experience and knowledge base of the standard setters regarding an issue on which standard practice is being considered (Taylor \& Turley, 1986, p. 70). For instance, the mandatory financial disclosure requirement setters in the UK, the Accounting Standards Committee (ASC), depend upon companies' voluntary disclosure practices to develop a series of Statements of 
Standard Accounting Practices (SSAPs) from the 1970s to early 1990s, which comprise submissions of current practice and simple requirements of standard formats (see Taylor \& Turley, 1986). Furthermore, in 2002 and early 2004, the US Financial Accounting Standards Board (FASB) commenced a project to codify the entire generally accepted accounting practice literature into a single authoritative source (FASB, 2004). In July 2009, the FASB released the authoritative version of the FASB Accounting Standards Codification as the single source of authoritative nongovernmental U.S. Generally Accepted Accounting Principles (information available at www.fasb.org).

Furthermore, Dye (1986) proposes a positive relationship between increasing mandatory disclosure requirements and a subsequent increase in managerial incentives for voluntary disclosure. This is based on the idea that an increase in mandatory disclosure leads to an increase in managerial incentives to disclose more voluntary information for value maximisation expressed in a company's share price, which subsequently attracts investors, and then to raise their corporate capital as cheaply as possible, or to distinguish the value or quality of a companies' product. This is contrary to the assumption that increasing mandatory disclosure requirements will lead to a decline in the level of voluntary disclosure (Dye, 1986). Thus, in practice voluntary financial disclosure develops as a result of homogenous reasons. For instance, the existence of new mandatory disclosure requirements enhances managers' incentives to voluntarily disclose more information to distinguish their companies in the market from others in order to increase their market value so as to increase wealth.

Although Table 1 shows that there are many prior studies in the financial disclosure literature, only in recent years accounting scholars have turned their attention to examining the nature of the interaction between levels of mandatory and voluntary disclosures in corporations' financial reporting, to explain how the levels of mandatory or voluntary disclosure may affect any incremental reporting regarding both types of disclosures. Al-Razeen \& Karbhari (2004) tested the relationship between existing mandatory disclosure and an increase in the level of voluntary disclosure in the Saudi Arabian environment. They tested this relationship by constructing three separate disclosure indices: (1) an index containing mandatory disclosure items, (2) an index containing voluntary disclosure items that are closely relate to mandatory disclosure, and (3) an index containing voluntary disclosure items that are not closely related to mandatory disclosure. Their analyses revealed that there was a significant, positive correlation between mandatory disclosure and voluntary disclosure related to the mandatory disclosure index. Their study focussed only on one reporting year, unlike the current study, which examines the relationship between mandatory and voluntary financial disclosure before and after the developments in mandatory disclosure requirements to provide a full image of how increasing mandatory disclosure could impact on the practice of voluntary financial disclosure. Naser \& Nuseibeh (2003) undertook another empirical investigation in the Saudi Arabian environment and found a positive and significant association between mandatory and voluntary disclosure. Similarly, Abayo et al. (1993) found a significant, positive relationship between mandatory and voluntary information in annual reports of Tanzanian companies. Furthermore, Einhorn (2005) established a model for analysing how companies' voluntary disclosure strategies are affected by their own mandatory disclosures. The model shows that voluntary disclosure can be significantly affected by the scope of mandatory disclosure.

However none of these studies investigated how the existing voluntary disclosure practices affect the incremental content of mandatory disclosure requirements. Furthermore, none of the prior studies provide any level of theoretical background to explain how mandatory disclosure requirements can be a product of voluntary disclosure practices. The lack of theoretical background has created a lacuna in the financial reporting context and in the guidance among accounting researches. This paper attempts to bridge this gap by testing codification theory as a theoretical foundation considering the issue of financial reporting requirements' developments. Also this paper is the first to examine this theory in the emerging economies' context.

\section{Research Design}

\subsection{Research Hypotheses' Development}

The main objective of this study is to test codification theory. The Jordanian financial reporting environment is seen as a rich area to examine this theory because significant developments changed the Jordanian financial reporting system. The Jordanian financial reporting framework before 1998 lacked clear financial reporting requirements and guidance for what should be disclosed and how companies should prepare their annual reports (Al-Akra et al., 2009; Hutaibat et al., 2011). However, a new regulatory system was introduced for what was in effect a new Jordanian capital market in 1998, as the Jordanian financial market was transformed into a modern capital market with a new legal framework, under the Securities Law 1997. This included a new capital market, which was divided among three institutions, the Jordan Securities Commission (JSC), the Amman Stock 
Exchange (ASE), and the Securities Depository Centre (SDC) (Al-Akra et al., 2009; Hutaibat et al., 2011). Furthermore, in 2002 the JSC introduced new extensive financial disclosure requirements imposed upon companies listed on the ASE, and for the first time listed Jordanian companies were required to adopt the full version of International Financial Reporting Standards (IFRS) in periodic financial statements (Al-Akra et al., 2009; Hutaibat et al., 2011). Based on these facts, it is concluded that voluntary financial information formed the major part of Jordanian corporations' annual reports before 1998.

This study tests codification theory by examining the association between the voluntary financial disclosure practices before 1998 and the new developments in the mandatory financial disclosure requirements by the JSC in 1998. This may explain how the development in mandatory disclosure practices depends upon voluntary disclosure practices, as codification theory asserts that in practice mandatory disclosure requirements and standards do not develop due to exogenous reasons (Von Alberti-Alhtaybat et al., 2012). The existence of these requirements depends upon companies' voluntary disclosure practices. The first question here is whether the new mandatory disclosure requirements by the JSC in 1998 are associated with voluntary financial disclosure practice before 1998. The answer to this question will be provided through testing the following hypothesis:

H1: There is no association between companies' voluntary disclosure practices before 1998 and the new JSC mandatory disclosure requirements imposed upon listed companies on ASE in 1998.

The second question of the current study is the extent to which Jordanian companies' compliance level with the new JSC mandatory disclosure requirements imposed upon sampled companies is associated with Jordanian companies' voluntary disclosure practices before 1998. The answer to this question will be provided through testing the following hypothesis:

H2: There is no association between companies'voluntary disclosure practices before 1998 and the Jordanian companies' compliance level with the new JSC mandatory disclosure requirements imposed upon sampled companies.

\subsection{Research Method and Sample Selection}

To test these hypotheses, a disclosure index was developed and used as a research instrument, which has dominated academic financial reporting research (Marston \& Shrives, 1991; Ahmed \& Courtis, 1999; Coy \& Dixon, 2004; Guthrie \& Abeysekera, 2006; Hanafi et al., 2009). Using a disclosure index as research method for testing codification theory is possible by empirically analysing the Jordanian corporations' annual reports before and after the first introduction of the new mandatory disclosure requirements by JSC in 1998, specifically, by studying the contents of Jordanian corporations' voluntary disclosure before 1998 and assessing their association with new financial disclosure requirements imposed upon companies listed on ASE in 1998. Furthermore, Jordanian corporations' compliance with new financial disclosure requirements imposed upon companies listed on ASE in 1998 can be measured, and their association with voluntary disclosure before 1998 can be assessed.

To achieve these objectives the years 1997 and 2008 were chosen for the current investigation. 1997 was chosen as the last year before the disclosure changes in 1998, while 2008 was chosen as year after 1998 because it was the last year during which all firms of the original sample had published annual reports available. After 2008 the world financial crisis led to the insolvency of several firms of the original sample. The researcher was able to only collect 51 useable published annual reports of Jordanian manufacturing corporations listed on the ASE in 1997 and 2008, which represent $73 \%$ of total listed manufacturing companies in 1997 and $56 \%$ of total listed manufacturing companies in 2008. Only manufacturing companies were included in this study as other companies, such as banks, insurance and investment companies have specific accounting issues (and in some cases are subject to particular accounting requirements not relevant for most companies), thus this study is limited to manufacturing companies. This study, however, does not measure the extent of voluntary financial reporting in Jordan in 1997 or mandatory financial disclosure in Jordan in 2008, nor does this study evaluate, explain or judge such practices among Jordanian companies in both years.

The current mandatory disclosure requirements' index represents the Jordanian financial reporting environment as it was based on mandatory items required by JSC's Securities Law and the 2002 Securities Law with its amendments in 2004. Table 2 summarises and itemises these requirements in form of a checklist including 45 mandatory items. It was decided to use the dichotomous approach to coding whether an item listed on the current checklist was disclosed by Jordanian corporations in 1997 and 2008 (coded as ' 1 ') or not disclosed (coded as ' 0 '). For each annual report being studied one score was determined, 'Total disclosed Items' (TDI). The total score for each index is computed by dividing the TANDI by 45, 'Total Index Items'. (TII) 
Table 2. The mandatory disclosure requirements by JSC

1. The Chairman's speech

2. The Board of Director's report, included

3. Description of any governmental protection or privileges with the period such is applied thereto.

4. A description of any patents or concessions that were granted to the company

5. Description of any decisions adopted by the Government, international organizations or otherwise which has material effect on the company's operations, products or competitive ability.

6. To which extent the company abides with the international quality standards

7. The company's accomplishments with figures

8. A description of significant events that the company encountered during the fiscal year.

9. The competitive status of the company within the sector of its activities

10. The company's main market is shared between the domestic market and in foreign markets if possible

11. Degree of dependence on specific providers and/or main customers where such constitutes (10\%) or more of aggregate purchases and/or sales or revenues respectively

12. The financial effect of extraordinary transactions

13. Time chain of incurred profits or losses, distributed profits, the shareholder's net equity and, the prices of securities issued by the company, for a period of no less than five years

14. Analysis of the company's financial status and actions results during the fiscal year.

15. Significant future developments including any expansions or new projects,

16. The company's future plan for at least one coming year

17. The expectations of the board of directors of the company's actions results

18. Amount of auditing fees for the company and the affiliates thereof

19. Description of the main company's activities, and geographical locations for each activity

20. Volume of capital investment in each activity

21. Number of employees in each activity

22. Description of affiliated companies

23. Nature of affiliated companies' work and fields of their activities

24. Names of the members of the board of directors

25. Names and titles of senior executive managers and a resume of each

26. Number of securities issued by the Company

27. Securities owned by any member of the board of directors and senior executive manager and their relatives, and companies controlled by any of them, compared with the preceding year.

28. Privileges and bonuses that the Chairman and members of the board of directors and senior executive managers enjoy during the fiscal year

29. All amounts received by them as wages, fees, salaries, bonuses and others

30. Amounts paid to them as travel and transportation expenses inside and outside the Kingdom.

31. Donations and grants made by the Company during the fiscal year

32. Names of senior shareholders of shares issued by the Company

33. The number of shares owned by each of senior shareholders where such ownership amounts to $5 \%$ or more, compared with the preceding year.

34. Organizational structure of the issuing company

35. Company appointing policy

36. Number of employees

37. The employees' qualification categories

38. The employees' turn-over ratio

39. The employees' rehabilitation and training programs

40. Contracts, projects and commitments concluded by the issuing company with the chairman or members of the board of directors, the director general, any employee of the company or their relatives.

41. The company's contribution in serving the environment and the local society

42. The company's annual financial statements audited by its auditors, compared with the preceding year, which shall include the following: balance sheet, profits and losses account, cash-flow list, changes in the shareholders equity.

43. The company's auditor's report on the company's annual financial statements including a statement that auditing procedures have been conducted according to IAS.

44. A declaration from the company's board of directors that, according to the board's knowledge and beliefs, there had been no significant matters affecting the continuity of the company during the following fiscal year.

45. A declaration from the company's board of directors of its responsibility for preparing the financial statements and for providing effective control system in the company

\section{Analysis}

The main finding of the paper, as shown in Table 3, is that Jordanian manufacturing companies disclosed a 
considerable level of JSC's disclosure requirements voluntarily in 1997. Also Table 3 exhibits the average of JSC's requirements voluntarily disclosed by Jordanian manufacturing companies was around 39\% of 45 JSC's mandatory items. Table 3 shows that Jordanian manufacturing companies did not fully comply with the JSC's mandatory disclosure requirements in 2008. Although full compliance with the JSC's requirements was expected, given that these requirements were entirely voluntary items in 1997, 73\% level of compliance with the disclosure requirements of the JSC in 2008 is considered a significant level of compliance. Comparatively, no full compliance was found in different countries around the world, for instance, Ahmed \& Nicholls (1994) found that none of the companies in Bangladesh disclosed all mandatory items; and they found only $58.7 \%$ of the mandatory disclosure index items were disclosed on average. Owusu-Ansah (1998) found 74.43\% as a mean score of companies' compliance with mandatory disclosure requirements in Zimbabwe. Tower et al. (1999) found a variation in the level of companies' compliance in six countries namely: Australia with an average compliance of $94 \%$, Thailand with an average compliance of $93 \%$, Singapore with an average compliance of $90 \%$, Malaysia with an average compliance of $90 \%$, Hong Kong with an average compliance of $89 \%$, and Philippines with an average compliance of 88\%. Finally, Glaum \& Street (2003) found that 83.7\% was the level of compliance with mandatory disclosure requirements in Germany.

The significant level of compliance with JSC's requirements in 2008 confirms that reporting mandatory requirements in practice do not change due to exogenous reasons, as accounting standards depend on what disclosures companies provide voluntarily. Therefore, this is considered pioneer empirical evidence supporting codification theory.

Table 3. Descriptive statistics of Jordanian companies total disclosed items and total index score of JSC's requirements in year 1997 and 2008

\begin{tabular}{lcccc}
\hline Year 1997 & Mean & SD & Minimum & Maximum \\
\hline Total JSC's Item score & 17.47 & 5.53 & 12 & 36 \\
Total JSC's Index score & 0.390 & 0.123 & 0.27 & 0.80 \\
\hline Year 2008 & & & & \\
\hline Total JSC's Item score & 30.25 & 7.39 & 10 & 41 \\
Total JSC's Index score & 0.7257 & 0.15728 & 0.26 & 0.95 \\
\hline
\end{tabular}

Furthermore, codification theory is tested in this paper through measuring the association between the level of voluntary disclosure in the companies' annual reports in 1997, measured by using JSC's requirements in 1998, and the level of compliance with JSC's disclosure requirements in 2008. Table 4 shows the results of Kendall's correlation test for the association between the disclosure indices in 1997 and disclosure indices in 2008. This result indicates a significant, positive relationship between the level of voluntary disclosure practices in 1997 and the level of compliance with the JSC mandatory disclosure requirements in 2008. This relationship suggests that in 1998 the JSC took the existing Jordanian companies' voluntary financial disclosure practices and codified these practices into mandatory disclosure requirements.

Table 4. The correlation between the values of disclosure indices in 1997 and 2008

\begin{tabular}{lcc}
\hline Kendall's tau_b & Total JSC's Index score 2008 \\
\hline Total JSC's Index score in 1997 & Correlation Coefficient & $0.341\left(^{*}\right)$ \\
& Sig. (1-tailed) & 0.000 \\
$\mathrm{~N}$ & 51 \\
\hline
\end{tabular}

Note. $*$ Correlation is significant at the 0.01 level (1-tailed).

Based on this result the alternative hypotheses $H 1, H 2$ can be accepted. These results provide empirical evidence supporting the argument for codification theory that, in practice, reporting mandatory requirements depend on what companies disclose voluntarily (Dye, 1986).

\section{Discussion and Conclusions}

Prior literature on developments of the legal financial reporting environment has neglected to deal with any theoretical foundation in explaining the developments in mandatory disclosure requirements. Codification theory 
addresses the development of financial reporting regulation in the form and in the content at any time and in any place depending upon the existing practices at that time and in that place (Von Alberti-Alhtaybat et al., 2012). This paper focuses on codification theory as an attempt to fill the gap in the accounting theoretical legal literature by arguing that an optimal voluntary disclosure practice is the hybrid stand in which regulation setters could codify this optimal voluntary practice as mandatory requirements. This may balance the costs and benefits to all issuers and to the government.

The analyses in this paper show that there was a considerable level of JSC's requirements voluntarily disclosed by Jordanian manufacturing companies, and a significant level of compliance with these requirements in 2008. In the same context, several studies measured the level of compliance with mandatory disclosure requirements before and after 1998, and reported that that level of Jordanian compliance had significantly improved overtime. For instance, Solas (1994) measured the level of compliance of Jordanian listed companies with what was known as mandatory disclosure requirements in 1988, and reported a mean disclosure index of $46.35 \%$, which he considered to be unacceptably low. Al-Akra et al. (2010a) examined the effects of privatisation, changes in mandatory disclosure requirements and governance mandates on the levels of disclosure of 80 listed nonfinancial companies comparing compliance with disclosure requirements in 1996 and 2004. Al-Akra et al. (2010a) found that Jordanian companies' compliance with the disclosure requirements had significantly improved in 2004, e.g. a mean disclosure level of $79 \%$, compared to $55 \%$ in 1996. Hutaibat et al. (2011) investigated mandatory disclosures in Jordan in 2008 after the regulatory changes in 1998, and they reported that aggregate levels of mandatory disclosure had increased in comparison to prior studies, and that Jordanian companies' compliance with mandatory disclosure requirements was at $83 \%$. Based on these prior studies the development trend of the level of Jordanian compliance with disclosure requirements during the last 20 years is illustrated in Exhibit 1 below:

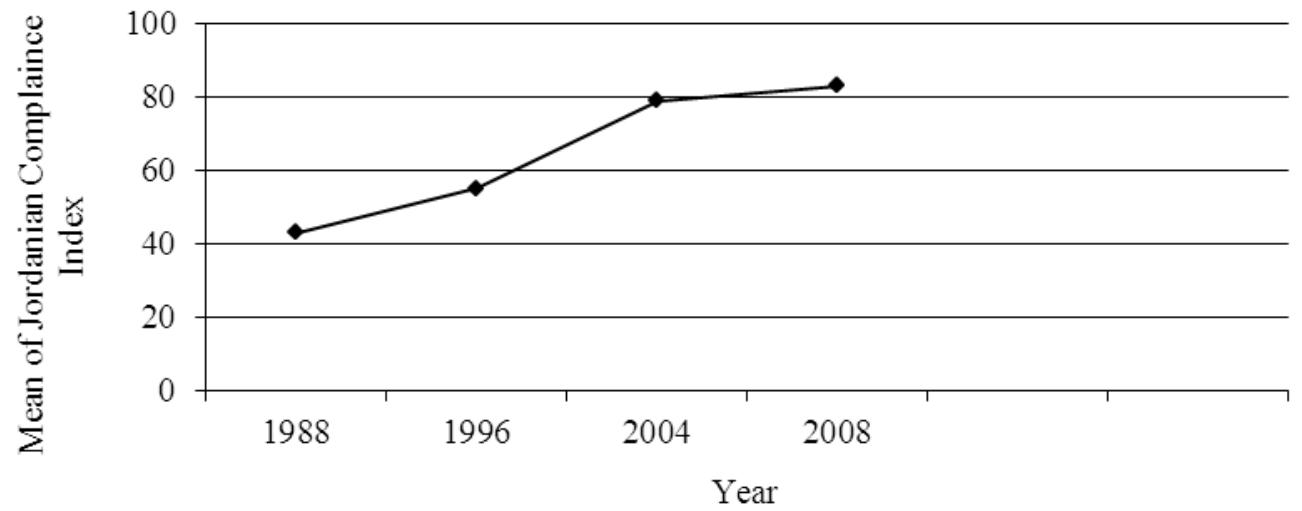

Figure 1. The development trend of the level of Jordanian companies' compliance with the disclosure requirements

These developments of the level of compliance with mandatory disclosure requirements in Jordan over the last 20 years can be explained through codification theory. Voluntary disclosure in the Jordanian companies' financial reporting before 1998 was the major part of its practices, and mandatory disclosure requirements were imposed in 1998 for mandatory disclosure to be the major part of Jordanian companies' annual reports after 1998. Based on the above it can be argued the JSC in 1998 was involved in a role similar to the UK Accounting Standards Committee (ASC) role of formulating a series of SSAPs from the 1970s to early 1990s, which comprised submissions of current practice and were simply requirements of standard format (see Taylor \& Turley, 1986). Thus, codifying an existing optimal voluntary practice in Jordan as a mandatory requirement will, firstly, increase the level of compliance with the new mandatory disclosure requirements due to familiarity, as these items before being mandatory were disclosed voluntarily by Jordanian companies. In a similar context, Abd-Elsalam \& Weetman (2003), in their study of the adoption of international standards in Egypt, suggest that lack of familiarity with some requirements of international standards could have lead to under-compliance. Secondly, codifying existing optimal voluntary practices as mandatory requirements supports cost effectiveness through reduced costs of compliance and analysis from the corporations' side, as well as reduces the costs associated with forming financial reporting standards, as regulation setting can be a very costly process to the 
government.

This paper benefits future accounting standard setters in emerging economies, thus opens a gateway for these standard setters, as codification theory emphasises that the already existent voluntary financial disclosure practice can be a major factor behind forming and developing mandatory disclosure requirements and standards. The preparers and the auditors provide an optimal level of financial disclosure to meet users' needs, which will then be codified by regulatory bodies and regulatory setters as mandatory disclosure requirements. The familiarity and the cost reduction in dealing with the new mandatory requirements that used to be voluntary practices are expected to yield a high level of compliance. This paper also offers a new platform for future research exploring new developments of financial reporting in relation to codification theory.

\section{Acknowledgment}

This research was undertaken during my sabbatical leave in 2012/2013, at the Accounting Department, Faculty of Economics and Administration, King Abdulaziz University Jeddah, Saudi Arabia. I would like to thank Al-Hussein Bin Talal University, Ma'an - Jordan, for their support.

\section{References}

Abayo, A. G., Adams, C. A., \& Roberts, C. B. (1993). Measuring the quality of corporate disclosure in less developing countries: the case of Tanzania. Journal of International Accounting, Auditing \& Taxation, 2(2), 145-158. http://dx.doi.org/10.1016/1061-9518(93)90003-C

Abd-Elsalam, O. H., \& Weetman, P. (2003). Introducing international accounting standards to an emerging capital market: relative familiarity and language effect in Egypt. Journal of International Accounting, Auditing \& Taxation, 12(1), 63-84. http://dx.doi.org/10.1016/S1061-9519(03)0000-8

Abu-Nassar, M. (1993). The development of financial reporting in jordan, a survey of preparers' and users' attitudes and reporting practices. Unpublished Doctoral Thesis, University of Kent.

Abu-Nassar, M., \& Rutherford, B. A. (1996). External Users of Financial Reports in Less Developed Countries: the Case of Jordan. British Accounting Review, 28(1), 73-87. http://dx.doi.org/10.1006/bare.1996.0004

Abu-Nassar, M., \& Rutherford, B. A. (2000). External reporting in less developed countries with moderately sophisticated capital markets: a study of user needs and information provision in Jordan. Research in Accounting in Emerging Economies, (4), 227-246.

Ahmed, K., \& Courtis, J. K. (1999). Associations between corporate characteristics and disclosure levels in annual reports: a meta-analysis. British Accounting Review, 31(1), 35-61. http://dx.doi.org/10.1006/bare.1998.0082

Ahmed, K., \& Nicholls, D. (1994). The impact of non-financial company characteristics on mandatory disclosure compliance in developing countries: the case of Bangladesh. The International Journal of Accounting, 29(1), 62-77.

Akerlof, G. A. (1970). The market for 'lemons': quality uncertainty and the market mechanism. Quartly Journal of Economics, 84(3), 488-500. http://dx.doi.org/10.2307/1879431

Al-Akra, M., Ali, M. J., \& Marashdeh, O. (2009). Development of accounting regulation in Jordan. The International Journal of Accounting, 44, 163-186. http://dx.doi.org/10.1016/j.intacc.2009.03.003

Al-Akra, M., Eddie, I., \& Ali, M. J. (2010a). The influence of the introduction of accounting regulation on mandatory disclosure compliance: evidence from Jordan. British Accounting Review, 42, 170-186. http://dx.doi.org/10.1016/j.bar.2010.04.001

Al-Akra, M., Eddie, I., \& Ali, M. J. (2010b). The association between privatisation and voluntary disclosure: evidence from Jordan. Accounting and Business Research, 40(1), 55-74. http://dx.doi.org/10.1080/00014788.2010.9663384

Al-Htaybat, K., \& Napier, C. (2004). Mandatory disclosure in the annual reports of Jordanian manufacturing companies before and after 1998. Paper presented at the Eighth Annual Financial Reporting \& Business Communication Research Conference, Cardiff Business School, 1-2 July 2004.

Al-Htaybat, K., (2011). Corporate online reporting in 2010: a case study in Jordan. Journal of Financial Reporting and Accounting, 9(1), 1985-2517. http://dx.doi.org/10.1108/19852511111139778

Alrazeen, A., \& Karbhari, Y. (2004). Interaction between compulsory and voluntary disclosure in Saudi Arabian corporate annual reports. Managerial Auditing Journal, 19(3), 351-360. 
http://dx.doi.org/10.1108/02686900410524364

Aly, D., Jon, S., \& Hussainey, K. (2010). Determinants of corporate internet reporting: evidence from Egypt. Managerial Auditing Journal, 25(2), 182-202. http://dx.doi.org/ 10.1108/02686901011008972

Andrikopoulos, A. (2007). Financial reporting practices on the internet: the case of companies listed in the Cyprus stock exchange. Working paper, University of the Aegean, Greece.

Ashbaugh, H., Johnstone, K. M., \& Warfield, T. D. (1999). Corporate reporting on the internet. Accounting Horizons, 13(3), 241-258. http://dx.doi.org/ 10.2308/acch.1999.13.3.241

Barrett, M. E. (1975). Annual report disclosure: are american reports superior? Journal of International Business Studies, 6(2), 15-24. http://www.jstor.org/stable/154200

Barrett, M. E. (1976). Financial reporting practices: disclosure and comprehensiveness in an international setting. Journal of Accounting Research, 14(1), 10-25. http://www.jstor.org/stable/2490455

Beattie, V., McInnes, B., \& Fearnley, S. (2004). A methodology for analysing and evaluating narratives in annual reports: a comprehensive descriptive profile and metrics for disclosure quality attributes. Accounting Forum, 28, 205-236. http://dx.doi.org/10.1016/j.accfor.2004.07.001

Bonson, E., \& Escobar, T. (2002). A survey on voluntary disclosure on the Internet: empirical evidence from 300 European Union companies. The International Journal of Digital Accounting Research, 2(1), $27-51$. http://dx.doi.org/10.4192/1577-8517-v2 2

Bozcuk, A., Arzova, S. B., \& Aslan, S. (2008). Internet financial reporting: the case of Turkey. Akdeniz University, Antalya, Turkey. Retrieved from http://ssrn.com/abstract=1490523

Buckland, R., Suwaidan, M., \& Thomson, L. (2000). Companies' voluntary disclosure behaviour when raising equity capital: a case study of jordan. Research in Accounting in Emerging Economies, 4, 247-266.

Buzby, S. L. (1975). Company size, listed versus unlisted stock, and the extent of financial disclosure. Journal of Accounting Research, 13(1), 16-37. http://dx.doi.org/10.2307/2490647

Cairns, D. (2000). IAS lite is alive and well. Accountancy, 127, 98-99.

Cerf, R. A. (1961). Corporate reporting and investment decisions. The University of California Press, Berkeley.

Chau, G. K., \& Gray, S. J. (2002). Ownership structure and corporate voluntary disclosure in Hong Kong and Singapore. International Journal of Accounting, $247-265$. http://dx.doi.org/10.1016/S0020-7063(02)00153-X

Choi, F. D. S. (1973). Financial disclosure and entry to the european capital market. Journal of Accounting Research, 11(2), 159-175. http://dx.doi.org/10.2307/2490187

Chow, C. W., \& Wong-Boren, A. (1987). Voluntary financial disclosure by mexican corporations. Accounting Review, 62(3), 533-541. Retrieved from http://www.jstor.org/stable/247575

Cooke, T. E. (1989). Voluntary corporate disclosure by swedish companies. Accounting and Business Research, 19(74), 113-124. http://dx.doi.org/10.1111/j.1467-646X.1989.tb00009.x

Cooke, T. E. (1991). An assessment of voluntary disclosure in the annual reports of Japanese corporations. International Journal of Accounting, 26(1), 174-189.

Cooke, T. E. (1992). The impact of size, stock market listing and industry type on disclosure in the annual reports of Japanese listed corporations. Accounting and Business Research, 22(87), 229-237. http://dx.doi.org/10.1080/00014788.1992.9729440

Cooke, T. E. (1993). Disclosure in Japanese corporate annual reports. Journal of Business Finance \& Accounting, 20(4), 521-535. http://dx.doi.org/10.1111/j.1468-5957.1993.tb00272.x

Cooke, T. E. (1998). Regression analysis in accounting disclosure studies. Accounting and Business Research, 28(3), 209-224. http://dx.doi.org/10.1080/00014788.1998.9728910

Cooke, T. E., \& Wallace, O. (1990). Financial disclosure regulation and its environment: a review and further analysis. Journal of Accounting and Public Policy, 9, 79-110. http://dx.doi.org/10.1016/0278-4254(90)90013-P

Cooper, K., \& Keim, G. D. (1983). The economic rationale for the nature and extent of corporate financial disclosure regulation: a critical assessment. Journal of Accounting and Public Policy, 2, 189-205. http://dx.doi.org/10.1016/0278-4254(83)90024-8 
Coy, D., \& Dixon, K. (2004). The public accountability index: crafting a parametric disclosure index for annual reports. The British Accounting Review, 36(1), 79-106. http://dx.doi.org/10.1016/j.bar.2003.10.003

Craven, B. M., \& Marston, C. L. (1999). Financial reporting on the internet by leading UK companies. European Accounting Review, 8(2), 321-333. http://dx.doi.org/ 10.1080/096381899336069

Debreceny, R. S., Gray, G. L., \& Mock, T. J. (2001). Financial reporting web sites: what users want in terms of form and content. The International Journal of Digital Accounting Research, 1(1), 1-24. http://dx.doi.org/10.4192/1577-8517-v1_1

Depoers, F. (2000). A cost-benefit study of voluntary disclosure: some empirical evidence from French listed companies. European Accounting Review, 9(2), 245-263. http://dx.doi.org/10.1080/09638180050129891

Desoky, A. (2009). Company characteristics as determinants of internet financial reporting in emerging markets: the case of Egypt. Accounting in Emerging Economies. Research in Accounting in Emerging Economies, 9, 31-71. http://dx.doi.org/10.1108/S1479-3563(2009)0000009004

Despina, A., \& Demetrios, P. (2009). The web-based financial reporting adopted by the listed companies in the Athens Stock Exchange. Journal of Modern Accounting and Auditing, 5(7), 7-20.

Dye, R. (1986). Proprietary and non-proprietary disclosures. Journal of Business, 59(2), 331-366. http://dx.doi.org/10.1086/296331

Dye, R. A. (1985). Strategies accounting choice and the effect of alternative financial reporting requirements. Journal of Accounting Research, 23(2), 544-574. http://dx.doi.org/10.2307/2490910

Einhorn, E. (2005). The nature of the interaction between mandatory and voluntary disclosures. Journal of Accounting Research, 43(4), 593-621. http://dx.doi.org/10.1111/j.1475-679X.2005.00183.x

Ettredge, M., Richardson, V. J., \& Scholz, S. (2002). Dissemination of information for investors at corporate web sites. Journal of Accounting and Public Policy, 21, 357-369. http://dx.doi.org/10.1016/S0278-4254(02)00066-2

FASB. (2004). Codification and Retrieval Project Report: The FASB Embark on Historic Change to the Structure of U.S. Accounting Standards. Retrieved from http:/www.fasb.org/articles\&reports/

Fulbier, R. U., \& Sellhorn, T. (2006). Methodological approaches to accounting research-Evidence from EAA annual congress. Social Science Network Research (SSRN). Working Paper Series. January. Retrieved from http://ssrn.com/abstract=985119

Glaum, M., \& Street, D. C. (2003). Compliance with the disclosure requirements of Germany's new market: IAS versus US GAAP. Journal of International Financial Management and Accounting, 14(1), 64-100. http://dx.doi.org/10.1111/1467-646X.00090

Gowthorpe, C., \& Amat, O. (1999). External reporting of accounting and financial information via the internet in Spain. The European Accounting Review, 8(2), 365-371. http://dx.doi.org/10.1080/096381899336096

Gray, S. J. (1988). Towards a theory of cultural influence on the development of accounting systems internationally. ABACUS, 24(1), 1-15. http://dx.doi.org/10.1111/j.1467-6281.1988.tb00200.x

Guthrie, J., \& Abeysekera, I. (2006). Content analysis of social, environmental reporting: what is new? Journal of Human Resource Costing and Accounting, 10(2), 114-26. http://dx.doi.org/10.1108/14013380610703120

Hanafi, S. R. B. M., Kasim, M. A. B., Ibrahim, M. K. B., \& Hancock, D. R. (2009). Business reporting on the internet: development of a disclosure quality index. International Journal of Business and Economics, 8(1), $55-79$.

Haniffa, R., \& Cooke, T. E. (2002). Culture, corporate governance and disclosure in Malaysian corporations. ABACUS, 38(3), 317-349. http://dx.doi.org/10.1111/1467-6281.00112

Helles, S. A. S. (1992). The evolution of accounting in developing countries the study of Jordan. Unpublished Doctoral Thesis, University of Hull.

Hossain, M., Tan, L. M., \& Adams, M. (1994). Voluntary disclosure in an emerging capital market: some empirical evidence from companies listed on the Kuala Lumpur stock exchange. International Journal of Accounting, 29(4), 334-351.

Hutaibat, K., Von Alberti, L., \& Al-Htaybat, K. (2011). The extent of compliance with mandatory financial disclosure requirements: evidence of IAS- lite from Jordan. Jordan Journal of Business Administration, 7(4), 709-736. 
Hutcheson, G., \& Sofroniou, N. (1999). The multivariate social scientist. SAGE Publications, London.

Inchausti, B. G. (1997). The influence of company characteristics and accounting regulation on information disclosed by Spanish firms. European Accounting Review, 6(1), 45-68. http://dx.doi.org/10.1080/096381897336863

Jensen, M. C., \& Meckling, W. H. (1976). Theory of firm: managerial behavior, agency costs and ownership structure. Journal of Financial $146-153$. http://dx.doi.org/10.1016/0304-405X(76)90026-X

Joshi, P., \& Al-Modhahki, J. (2003). Financial reporting on the internet: Empirical evidence from Bahrain and Kuwait. Asian Review of Accounting, 11(1), 88-101. http://dx.doi.org/10.1108/eb060764

Lai, S. C., Lin, C., Li, H. C., \& Wu, F. H. (2010). An empirical study of the impact of internet financial reporting on stock prices. International Journal of Digital Accounting Research, 10, 1-26. http://dx.doi.org/10.4192/1577-8517-v10 1

Malone, D., Fries, C., \& Jones, T. (1993). An empirical investigation of the extent of corporate financial disclosure in the oil and gas industry. Journal of Accounting, Auditing and Finance, 8(3), $249-273$. http://dx.doi.org/10.1177/0148558X9300800306

Marston, C. (2003). Financial reporting on the Internet by leading Japanese companies. Corporate Communications, 8(1), 23-27. http://dx.doi.org/10.1108/13563280310458894

Marston, C. L., \& Shrives, P. J. (1991). The use of disclosure indices in accounting research: a review article. British Accounting Review, 23, 195-210. http://dx.doi.org/10.1016/0890-8389(91)90080

Marston, C., \& Polei, A. (2004). Corporate reporting on the Internet by German companies. International Journal of Accounting Information Systems, 5, 285-311. http://dx.doi.org/10.1016/j.accinf.2004.02.009

McNally, G. M., Eng, L. H., \& Hasseldine, C. R. (1982). Corporate financial reporting in New Zealand: an analysis of user preferences, corporate characteristics and disclosure practices fro discretionary information. Accounting and Business Research, 13(49), 11-19. http://dx.doi.org/10.1080/00014788.1982.9729725

Meek, G. K., Roberts, C. B., \& Gray, S. J. (1995). Factors influencing voluntary annual report disclosures by U.S., U.K., \& continental European multinational corporations. Journal of International Business Studies, 26(3), 555-572. http://dx.doi.org/10.1080/00014788.1982.9729725

Momany, M., \& Al-Shorman, S. (2006). Web-based voluntary financial reporting of Jordanian companies. International Review of Business Research Papers, 2(2), 127-139.

Mutter, C. M. (1993). (in Arabic). Evaluation of actual disclosure level in the financial statements of jordanian companies. DIRASAT in Jordan University, 20A(2), 116-169.

Naser, K. (1998). Comprehensiveness of disclosure of non-financial companies listed on the amman financial market. International Journal of Commerce and Management, 8(1), 88-119. http://dx.doi.org/10.1108/eb047365

Naser, K., \& Al-Khatib, K. (2000). The extent of voluntary disclosure in the board of directors. Statement. Advances in International Accounting, 13, 99-118.

Naser, K., \& Nuseibeh, R. (2003). Quality of financial disclosure reporting: evidence from the listed Saudi non-financial companies. International Journal of Accounting, 38(1), 41-69. http://dx.doi.org/10.1016/S0020-7063(03)00002-5

Naser, K., Al-Khatib, K., \& Karbhari, Y. (2002). Empirical evidence on the depth of corporate information disclosure in developing countries: The case of Jordan. International Journal of Commerce and Management, 12(3/4), 122-155. http://dx.doi.org/10.1108/eb047456

Nobes, C. (1998). Towards a general model of the reasons for international differences in financial reporting. ABACUS, 34(2), 162-187. http://dx.doi.org/10.1111/1467-6281.00028

Omar, B., \& Simon, J. (2011). Corporate aggregate disclosure practices in Jordan. Advances in Accounting incorporating Advances in International Accounting, 27(1), 166-186. http://dx.doi.org/10.1016/j.adiac.2011.05.002

Owusu-Ansah, S. (1998). The impact of corporate attributes on the extent of mandatory disclosure and reporting by listed companies in Zimbabwe. International Journal of Accounting, 33(5), 605-631. http://dx.doi.org/10.1016/028418699431645 
Oyelere, P., Laswad, F., \& Fisher, R. (2003). Determinants of internet financial reporting by New Zealand listed companies. Journal of International Financial Management and Accounting, 14(1), $26-63$. http://dx.doi.org/10.1111/1467-646X.00089

Patton, J., \& Zelenka, I. (1997). An empirical analysis of the determinants of the extent of disclosure in annual reports of joint stock companies in the Czech Republic. European Accounting Review, 6(4), 605-626. http://dx.doi.org/10.1080/09638189700000003

Pirchegger, B., \& Wagenhofer, A. (1999). Financial information on the Internet: a survey of the homepages of Austrian companies. European Accounting Review, 8(2), 383-395. http://dx.doi.org/10.1080/096381899336113

Posner, R. A. (1974). Theories of economic regulation. Bell Journal of Economics and Management Science, $5(2), 335-358$.

Radebaugh, L. H., \& Gray, S. J. (2002). International accounting and multinational enterprise (5th ed.). John Wiley \& Sons, Inc, USA.

Raffournier, B. (1995). The determinants of voluntary financial disclosure by Swiss listed companies. European Accounting Review, 4(2), 261-280. http://dx.doi.org/10.1080/09638189500000016

Roberts, C., Weetman, P., \& Gordon, P. (1998). International Financial accounting: a comparative approach. Financial Times Pitman Publishing, London.

Roger, B., Suwaidan, M., \& Thomson, L.(2000). Companies voluntary disclosure behavior when raising equity capital: a case study of Jordan. Research in Accounting in Emerging Economies, 4, 247-266.

Singhvi, S. S. (1968). Characteristics and implications of inadequate disclosure: a case study of India. International Journal of Accounting, 3(2), 29-43.

Singhvi, S. S., \& Desai, H. B. (1971). An empirical analysis of the quality of corporate financial disclosure. Accounting Review, 46(1), 129-138.

Solas, C. (1994). Financial reporting practice in Jordan: an empirical test. Advances in International Accounting, 7, 43-60.

Suwaidan, M. S. (1997). Voluntary disclosure of accounting information: the case of Jordan. Unpublished Doctoral Thesis, University of Aberdeen.

Tai, B. Y. K., Au-Yeung, P. K., Kwok, M. C. M., \& Lau, L. W. C. (1990). Non-compliance with disclosure requirements in financial statements: the case of Hong Kong companies. International Journal of Accounting, 25(1), 99-112.

Taylor, P., \& Turley, S. (1986). The regulation of accounting. Oxford: Basil Blackwell.

Verma., D. (2010). Web-based business reporting in Indian corporate sector. Journal of Knowledge Management Practice, 11(1).

Von Alberti, L., Al-Htaybat, K., \& Hutaibat, K. (2012). Mapping corporate disclosure theories. Journal of Financial Reporting and Accounting, 10(1), 73-94. http://dx.doi.org/10.1108/19852511211237453

Wallace, R. S. O. (1988). Corporate financial reporting in Nigeria. Accounting and Business Research, 18(72), 352-362. http://dx.doi.org/10.1080/00014788.1988.9729382

Wallace, R. S. O., \& Naser, K. (1995). Firm-Specific determinants of the comprehensiveness of mandatory disclosures in the corporate annual reports of firms listed on the stock exchange of Hong Kong. Journal of Accounting and Public Policy, 14, 311-368. http://dx.doi.org/10.1016/0278-4254(95)00042-9

Wallace, R. S. O., Naser, K., \& Mora, A. (1994). The relationship between the comprehensiveness of corporate annual reports and firm characteristics in Spain. Accounting and Business Research, 25(97), 41-53. http://dx.doi.org/10.1080/00014788.1994.9729927

Watson, A., Shrives, P., \& Marston, C. (2002). Voluntary disclosure of accounting ratios in the UK. British Accounting Review, 34(4), 289-313. http://dx.doi.org/10.1006/bare.2002.0213

Watts, R. L., \& Zimmerman, J. L. (1978).Towards a positive theory of the determination of accounting standards. The Accounting Review, LIII(1), 112-143.

Watts, R. L., \& Zimmerman, J. L. (1986). Positive accounting theory. New Jersey: Prenice Hall. 
Xiao, J. Z., Dyson, J., \& Powell, P. (1996).The impact of information technology on corporate financial reporting: a contingency perspective. British Accounting Review, 28(3), 203-27.

Xiao, J. Z., Jones, M. J., \& Lymer, A. (2002). Immediate trends in internet reporting. European Accounting Review, 11(2), 245-275. http://dx.doi.org/10.1080/09638180020017087a

Xiao, J. Z., Yang, H., \& Chow, C. W. (2004). The determinants and characteristics of voluntary Internet-based disclosures by listed Chinese companies. Journal of Accounting and Public Policy, 23, 191-225. http://dx.doi.org/10.1016/j.jaccpubpol.2004.04.002

Zhang, T., He, Y., \& Gao, S. S. (2007). The determinants of internet financial reporting: empirical evidence from China. Paper presented at the BAA Annual Conference, Royal Holloway, University of London, London.

\section{Copyrights}

Copyright for this article is retained by the author(s), with first publication rights granted to the journal.

This is an open-access article distributed under the terms and conditions of the Creative Commons Attribution license (http://creativecommons.org/licenses/by/3.0/). 